\title{
Current Issues in Flood Disaster: Challenges and Implications for Science and Technology to Enhance Environmental Education
}

\author{
Upa Callistus Terungwa
}

\author{
Department of Geography, College of Education, \\ Katsina-Ala, Benue State, Nigeria \\ Iyortyer Clara Torkwase \\ Department of Geography, College of Education, \\ Katsina-Ala, Benue State, Nigeria
}

\section{Doi:10.5901/ajis.2013.v2n6p61}

\begin{abstract}
The paper is on current issues in flood disaster. The paper discussed the effects of climate variability and change on the environment. The paper examined the challenges of flood disaster and implications of flood disaster for science and technology. The paper also discussed adaptation strategies for flood disaster. The paper concluded that the challenges of flood disaster have affected people negatively in flood areas resulting in disruption of socio-economic activities and loss of properties. Suggestions/recommendations were made that government should carryout flood adaptation strategies and enforce land use control measures to meet the prevailing challenges of flood.
\end{abstract}

Keywords: Climate change. Flood disaster. Adaptation. Science and Technology

\section{Introduction}

Climate is the average weather condition of a place over a long period of time. According to Wikipedia (2013), climate encompasses the statistics of temperature, humidity, atmospheric pressure, wind, precipitation, atmospheric particles and other meteorological elemental measurements in a given region over long periods. Zabbey and King (2007) opined that climate change means any change in climate overtime whether due to natural variability or as a result of intense human activities in the environment. Climate change is any alteration from elements of weather like temperature, humidity, pressure, wind and precipitation.

Morristown (2010) defined flood as an overflow of water onto normally dry land, the inundation of a normally dry area. In the same vein, Caldwell (2012) affirmed that flood is any high flow, overflow, or inundation by water which causes or threatens damage. Flooding can rise from overflowing rivers (river flooding), heavy rainfall over a short duration (flash flood) or an unusual inflow of sea water onto land (ocean flooding). Flood is an overflow of water that comes from a river or other bodies of water and causes or threatens damage.

Siepmann (1999) defined Science as the field of study which attempts to describe and understand the nature of the universe in whole part. Wikipedia (2013) viewed science as a systematic enterprise that builds and organizes knowledge in the form of testable explanations and predictions about the universe. Science is any type of knowledge-base that can have some predictable outcome. 
Technology according to Khali (2000) is all knowledge products, processes, tools, methods, and systems employed in the creation of goods or in providing services. Supporting the view, Lowe (1995) said technology is the structured application of scientific principles and practical knowledge to physical entities and systems. Technology is an object or set of operations created by man to assist in achieving some goal. Science is an organize body of knowledge while Technology is the application of science to make something that works.

\section{The Effects of Climate Variability and Change on the Environment}

Dinse (2009) defined climate change as the way climate fluctuates yearly above or below a longterm average value. Climate variability refers to short term (daily, seasonal, annual, inter-annual, several years) variations in climate. The effects of climate variability and change on environment may vary in terms of degree, magnitude, frequency and duration. Somarin (2010) opined that increased concentration of Green House Gas (GHGs) in the atmosphere causes disruptions in climate system such as changes in precipitation regime and frequency and severity of extreme events like typhoons, hurricanes, flood among others. Tunde, Adeleke and Adeniyi (2013) said effects of climate variability and change are caused by natural activities like interaction of the oceans and the atmosphere, changes in the energy received from the sun and volcanic eruptions while Human-induced alterations of the natural world have contributed to high increase in the rate of gaseous emissions into the atmosphere, thereby causing global warming. The environmental problems like recurring droughts, high rate of deforestation, and soil degradation among others may be exacerbated by climate change.

\section{Challenges of Flood Disaster}

Flood disaster according to Ezemonye and Emeribe (2011) is an unforeseen and sudden event that causes damage, destruction and human suffering. According to WHO (2002), Flood disaster is a happening that frequently cause damage including disruption to roads, rail lines, airport, electricity supply systems, water supplies and sewage disposal systems. Floods are the most recurring, widespread, disastrous and frequent natural hazards of the world. Adedeji, Oladesu and Bongwa (2012) Stressing on the challenges of flood said that, heavy rainfall coupled with bad human activities in relation to the environment and lack of drainage infrastructure in most Nigerian cities left hundreds of people distressed and homeless as a result of flood. Similarly, Nigerian Compass (2012) also viewed that, states such as Kogi, Kwara, Anambra, Delta, Cross River, Edo and Bayelsa were been caught up in the floods and hundreds of people were confirmed dead. Duru and Yusuf (2012) writing on flood in Benue State stated that, Worst hit by the devastation were houses within the banks of the river and most structures within five kilometers radius of the river and some of the communities were affected. In a related development, J enkins (2011) opined that, dirty water, mud and silt that floods bring into our homes, backyards, streets and local play grounds cause a range of conditions including diarrhea, skin disease and soft-tissue infections. Ken (2013) stated that, flood can distribute large amount of water and suspended river sediment over vast areas which help to replenish valuable topsoil components to agricultural lands. Queensland Government (2012) also affirmed that, flood events can result in long-term benefits to agricultural production by recharging water resource storages, especially in drier inland areas, and by rejuvenating soil fertility by silt deposition. Floods destroy homes, kill animals and humans alike but they also bring soil and new life to the land they affect. 


\section{Causes of Flood}

According to Wikipedia (2012), Heavy rainfall caused the Lamingo dam to overflow near Jos, sweeping across a number of neighborhoods in Jos and approximately 200 homes were submerged or destroyed. Identified causes of flood according to Atedhor, Odjugo and Uriri (2011) are increasing rainstorm, obstruction of drainage system; absence of drainage system, poor land use control, global warming and soil. Flooding arises mainly because of blocked natural and man-made drainages and poor maintenance of water dams/reservoirs which seldom give way after persistent heavy downpours.

\section{Implications of Flood Disaster for Science and Technology}

Development in any nation of the world is viewed in terms of how science and technology is able to combat factors that affect the citizens negatively like the aspect of flood disaster. Queensland (2012), enumerated these implications of flood disasters to include;

Socially: As most people are well aware, the immediate impact of flood will include loss of human life, damage to property, destruction of crops, loss of livestock, and deterioration of health conditions owing to water-borne diseases.

Economically: Damage to public infrastructure will affect a far greater proportion of the population. Flood damage to roads, rail networks and key transport hubs, such as shipping ports, can have significant impact on regional and national economies.

Psychologically: Floods will traumatize victims and their families for long periods of time. Displacement from one's home will cause continuous stress.

Environmentally: Flood will degrade already degraded systems, removal of vegetation in and around rivers, increased channel size, among others. According to I S D R (2013) science and technology will help to understand the mechanism of natural hazards and to analyse the transformation of these hazards into disasters. Science and Technology will provide knowledge and application of skills to put machineries in place to tackle the issue of flood disaster in any nation.

\section{Adaptation Strategies for Flood Disaster}

Discussing on flood adaptation strategies, Atedhor, Odjugo and Uriri (2010), pointed out that embankment; either concrete or sandy may be constructed to prevent water from entering residential houses. Adaptation options that would be effective for flood disaster in developing nations according to Kolawole, Olayemi and Ajayi (2011) include: (i) Environmental policy reforms, changes in urban and housing design, removal of laws that can inadvertently increase flood vulnerability.(iii) Capacity building to integrate climate change and its impact into urban development planning involving local communities, raising public awareness and education on climate change and enabling representation at international meetings. Planting of vegetation to reduce extra water, terracing hillsides to slow flow down hills as well as control of man-made channels to divert flood water among others will serve as adaptation strategies/control.

\section{Conclusion}

Flood can come from overflowing rivers, heavy rainfall over a short duration or an unusual inflow of sea-water onto the land, causing damage to lives and property. Effects of climate change vary in degrees and magnitude worldwide. Changing rainfall interfaced with anthropogenic factors like obstruction of drainage system, and poor control of land use resulting to increase flooding. The challenges of flood disaster have affected people negatively causing disruption of socio-economic 
activities and loss of properties, heavy rainfall coupled with bad human activities in relation to the environment and lack of drainage infrastructure in most cities, left hundreds of people distressed and homeless as a result of flood. Flooding will have a lot of implications on the citizens in terms of loss of lives and damage to properties, infrastructure, and displacement of people from their homes causing trauma, removal of vegetation in and around rivers, increasing channel size among others. However, these can be combated through the application of the knowledge of science and technology in controlling flood disaster in any nation. Adapting to flood disaster can be possible through construction of embankment, enactment of environmental laws to control landuse, educating people on the effects of climate change as well as planting of vegetation to reduce extra water, terracing hillsides to slow flow down hills as well as control of man-made channels to divert flood water.

\section{Recommendations/Suggestions}

- The government and other well meaning individuals should carry out flood adaptation strategies to meet the prevailing challenges and proper land use control be enforced to prevent people from blocking drainages and building on areas prone to flooding.

- Flood disaster education should be included in the syllabus of all levels of education e.g. primary, secondary and tertiary levels.

- An awareness campaign should be established both in urban and rural areas to educate people on flood disaster issues.

- Flood disaster officers should be appointed and charged with the responsibility of synthesizing citizenry on the effects of flood disaster in countries especially Nigeria.

- Flood disaster laws should be enacted and violators of flood disaster laws should be punished forth with. This will prevent and check citizens from blocking drainages and building on water channels.

\section{References}

Atedhor, G.O, Odjugo, P.A.O and Uriri, A.E. (2011). Changing rainfall and anthropogenic-induced flooding: Impacts and adaptation strategies in Benin City, Nigeria. Journal of Geography and Regional Planning 4(1) pp.42-52.

Aye, B. (2012). The National Disaster of a Spreading Flood. Retrieved February 3, 2013 from http://saharareporters.com/article/national-disaster-spreading-flood-baba-aye.

Caldwell, D.B. (2012). Definitions and General Terminology. Operations and services, Hydrological Programs. National weather service manual 10-59. Retrieved February 11, 2013 fro http://www.nws. noaa.gov/directives/.

Dinse, K. (2009). Climate variability and Climate Change. Retrieved may 28, 2013, from http://www.miseagrrant.umich.edu/.../climate/11-703-climate-variability-and-c

Duru, P and Yusuf, U. (2012, September 12). River Benue Surge: Disaster hits Makurdi. Vanguard. Retrieved February 18, 2013 from http://www.vanguardng.com/2012/ogriver-benue-surge-disasterhits-makurdi/.

Ezemonye, M.N and Emeribe, C.N.(2011).Flood characteristics and management Adaptations in parts of the imo river system. Ethiopian J ournal of Environmental studies and management, vol. 4, no.3.

ISDR. (2012). The Role of Science and Technology in Disaster Reduction. Retrieved February 19, 2013 from http://www.unisdr.org/.

Jenkins, R. (2011). Health risks remain after flood subsidies. Retrieved February 18, 2013 from http://www.abc.net.au/health/features/stories/2011/02/10/3135043.htm.

Ken, R. (2013). Environmental Effects of Floods. Retrieved February 9, 2013 from http://www.soest.hawaii.edu/GG/Ask/floods.html.

Khalil, T.M. (2000). The key to competiveness and wealth creation. Singapore McGraw Hill Book Co. 
Kolawole, O.M, Olayemi,A.B, and Ajayi,K.T.(2011).Managing Flood in Nigerian Cities: Risk analysis and adaptation options.Scholars Research Library 3(1) 17-24

Lowe, P. (1995). The Management of Technology: Perception and Opportunities, U.K, Chapman and Hall.

Morristown, T.N. (2010). Definition of flood and flash flood.Retrieved February 11, 2013 from http://www.5rh.noaa.gov/mrx/hydro/flooddef.php.

Odufuwa, B.O, Adedeji, O.H, Oladesu, J.O and Bongwa, A. (2012). Flood of Fury in Nigeria Cities. Journal of Sustainable Development (5) 7, 1-11.

Queensland Government. (2012). What are the consequences of flood. Retrieved February 9, 2013 from http://www.chiefscientist. qld.gov.au/publications/understanding-floods/consequences.aspx.

Siepmann, J.P. (1999). What is Science? J ournal of Theoretic (1) 1-3.

Tuned, A.M, Adeleke, E.A and Adeniyi, E.E. (2013.Impact of Climate Variability on Human Health in Ilorin, Nigeria. Environmental and Natural Resources (3)1, 1-134.

W.H.O. (2002). Floods: Climate change and Adaptation Strategies for human health. Report on a W.H.O meeting, London, United Kingdom.

Wikipedia.(2012). Nigeria Floods. Retrieved February 18, 2013 from http://en.wikipedia.org/wiki/ 2012_Nigeria_flood\#causes

Wikipedia.(2013). Ścience.Retrieved February 14, 2013 from http://en.wikipedia.org/wiki/science.

Wikipedia. (2013). climate Retrieved February 11, 2013, from http://en.wikipedia.org/wiki/climate.

Zabbey, N and King, D. (2007). Climate change and flood: Fate of Riverine Communities in the Niger Delta. Retrieved February 11, 3013, from http://www.google.com.ng/ search?=climatechangeandfloodbyZabbeyandKing. 
